\title{
SCREENING AND AGRONOMIC BENEFITS OF THE STAY-GREEN TRAIT IN COMMON BEAN GENOTYPES
}

\author{
SCREENING E CONTRIBUIÇÕES AGRONÔMICAS DO CARÁTER STAY-GREEN \\ EM GENÓTIPOS DE FEIJÃO
}

\author{
Rodolfo SCHMIT ${ }^{1}$; Rita Carolina de MELO $^{1}$; Nicole TREVISANI ${ }^{1}$; \\ Altamir Frederico GUIDOLIN ${ }^{1}$; Jefferson Luís Meirelles COIMBRA ${ }^{1}$ \\ 1. Universidade do Estado de Santa Catarina - UDESC, Centro de Ciências Agroveterinárias - CAV, Instituto de Melhoramento e \\ Genética Molecular - IMEGEM, Lages, SC, Brasil. rodolfoschmit09@ gmail.com.
}

\begin{abstract}
Selecting a trait linked to metabolic pathways that enhance resistance and tolerance to biotic and abiotic stresses may be an excellent alternative. A practical approach to increase the productivity of annual crops is to maximize the photosynthetic efficiency in plant breeding. The purpose of this study was to discriminate common bean genotypes during physiological senescence with regard to the stay-green trait and analyze its effects on other traits of agronomic interest. Ten common bean genotypes were analyzed in a randomized complete block design with three replications. The stay-green trait was assessed by visual scores at harvest. The chlorophyll $a$ content, chlorophyll $b$ and green pod color were also evaluated during senescence $(75,80,85,90$, and 95 days after sowing). Pod maturation of all evaluated genotypes was standard when they reached 95 days after sowing. The stay - green feature was detected only in the genotypes BRS Expedito, FT Tarumã and BAF071. Genetic variability in the mechanisms related to late senescence is indicated by: $i$ ) a high initial chlorophyll $a$ content; and ii) reduced chlorophyll degradation throughout senescence. Plants with staygreen properties were significantly correlated with a lower incidence and severity of plant pathology, greater stem diameter, and higher grain yield.
\end{abstract}

KEYWORDS: Phaseolus vulgaris L. Analysis of covariance. Late senescence. Biotic and abiotic stresses.

\section{INTRODUCTION}

Plant adaptation to adverse environments involves tolerance to multiple stresses acting simultaneously (ASSEFA et al., 2015). Common bean is extremely sensitive to thermal, water and nutritional variations (FAHAD et al., 2017). The identification of genotypic constitutions with traits that prevent yield decreases is essential (DOHLEMAN; LONG, 2009). Selecting a trait linked to metabolic pathways that enhance resistance and tolerance to biotic and abiotic stresses may be an excellent alternative (GREGERSEN et al., 2013). A practical approach to increase the productivity is to maximize the photosynthetic efficiency (ZHU et al., 2010).

The existence of genetic variability allows the selection of genotypes with late physiological senescence, maintaining the photosynthetic activity throughout the crop cycle (WANG et al., 2008). In plant breeding, this variant is called stay-green and is found in plants capable of maintaining their green vegetative structures (stems and leaves) even after physiological maturation of the reproductive structures (KUSABA et al., 2013). Senescence is a complex process, in which multiple cellular events occur in parallel or sequentially (LIM et al., 2007). Gene mutations leading to the suppression of ethylene, abscisic acid, and brassinosteroid and to strigolactone signal transduction are often associated with stay-green, indicating a complex signaling network of physiological senescence regulation (KUSABA et al., 2013).

It was observed that plants with stay-green in maize, sorghum and sunflower were tolerant to stress caused by drought, cold, pests, diseases and had a lower lodging rate. In wheat lines, the staygreen trait allowed a greater reserve accumulation in seeds close to physiological maturity, a critical stage for the increase in mean grain weight (SILVA et al., 2008). Maize hybrids with stay-green under drought stress ensured the permanent availability of new assimilates, and increased nitrogen uptake during grain filling (BORRELL; HAMMER, 2000).

It is believed that in common bean, the staygreen feature will be directly related to the prolongation of photosynthesis and can fortify the plant throughout the entire development (BACHMANN et al., 1994). Common bean plants with stay-green are associated with upright growth, and are more resistant to lodging (AGUIAR et al., 2000). In fact, few papers and studies have 
addressed the possible advantages and disadvantages of this trait in common bean (AGUIAR et al., 2000; CARMO et al., 2007). The purpose of this study was to discriminate common bean genotypes during physiological senescence in relation to the stay-green trait, as well as to correlate the effects of this on other traits of agronomic interest.

\section{CONTENTS}

The study was carried out in the experimental area of the Instituto de Melhoramento e Genética Molecular da UDESC (IMEGEM) arranged in a randomized block design with three replications. The experiment tested 10 common bean genotypes: 1-SPS Carioca, 2-Pérola, 3-IPR Uirapuru, 4-BRS Expedito, 5-BAF045, 6-SPS Preto, 7-Carioca MG, 8-BAF071, 9-FT-Tarumã and one mutant population of the Pérola genotype irradiated with 100 Gray, from gamma rays of ${ }^{60} \mathrm{Co}(10-$ PMP.100) in generation $\mathrm{M}_{8}$.

The stay-green trait was evaluated by two different methodologies:

a) Evaluation at harvest by the system of visual scores: 10 plants of the assessable area were evaluated, where score 1 - plants with over $80 \%$ green stems and leaves; 2 - plants with 60 to $80 \%$ green stems and leaves; 3 - plants with 40 to $60 \%$ green stems and leaves; 4 - plants with 20 to $40 \%$ green stems and leaves; 5 - plants with up to $20 \%$ green stems and leaves (WALULU et al., 1994; AGUIAR et al., 2000; CARMO et al., 2007).

b) Chlorophyll a and b leaf contents and green pod color (during physiological senescence): 10 Plants of the assessable area were indirectly and non-destructively evaluated, in three plant strata (basal, intermediate, apical), using a portable ClorofiLog chlorophyllometer (MONJE; BUGBEE, 1992). The chlorophyll $a$ and $b$ levels were evaluated five times $(75,80,85,90$, and 95 days). The green pod color was measured by digital image analysis, quantifying the percentage of green color in relation to the total pod area. The evaluation was performed using software Scion Image (MURAKAMI et al., 2005). The pod color was evaluated 85, 90 and 95 days after sowing.

Characteristics of agronomic interest were measured in 10 plants sampled for stay-green evaluation: vegetative cycle (days from emergence to flowering); reproductive cycle (days from flowering to harvest). In addition, the incidence and severity of plant diseases was quantified: anthracnose (on leaves and pods), angular spot (on leaves and pods), and bacterial blight. The evaluation was carried out during the pod filling stage (R9), by assigning grades from 1 to 9, according to the model proposed by Shoonhoven and Pastor Corrales (1987).

During harvest, the following traits were evaluated: plant lodging in a binary system ( 1 for upright and 0 for broken plants); stem diameter $(\mathrm{mm})$, insertion height of first pod $(\mathrm{cm})$; length of first pod $(\mathrm{cm})$; plant height $(\mathrm{cm})$; equatorial length of central leaflet $(\mathrm{mm})$; polar length of central leaflet $(\mathrm{mm})$; number of pods per plant; number of grains per plant; and 1000-grain weight (g). All plants of the assessable area were harvested and threshed by a plot harvester, to determine the grain yield $\left(\mathrm{kg} \mathrm{ha}^{-1}\right)$. In this study, a $1 \mathrm{~m}^{2}$ wooden frame was used to collect and weigh the loose grains and grains in the pods that were lost from the harvester (in $\mathrm{kg} \mathrm{ha}^{-1}$ ) (MESQUITA et al., 1998).

Chlorophyll $a$ and $b$ contents were subjected to univariate covariance analysis by the $\mathrm{F}$ test. The treatment factors genotype, season and plant stature and the possible interactions were considered. The vegetative cycle and reproductive cycle were adopted as covariates in the evaluation of chlorophyll contents. In case of significant effects for the factor season, we performed interactive analyses of nonlinear regressions to fit equations that best represent the phenomenon of physiological senescence. The agronomic contribution of staygreen (chlorophyll $a$ and $b$ scores and levels) to the other traits was investigated by genetic correlation analysis.

The univariate analysis of covariance showed a significant effect of the interaction (significant at $5 \%$ probability) of the seasons on the different genotypes (SES*GNT) (Table 1). Therefore, there is variability in the metabolic processes of physiological senescence, in which chlorophyll degradation and pod discoloration occur dissimilarly in the evaluated genotypes. No significant variation was detected with regard to the plant stratum on genotype senescence, indicating that there is no difference between senescence in genotypes with and without stay-green trait in common bean.

Evaluations of genotypes with different biological cycles on a same day after sowing, may imply in different results, because compare plants in distinct phenological stages (CARMO et al., 2007). Since this source of variation cannot be effectively controlled, covariance analysis can be used to reduce these effects. The growth and reproductive cycles of the studied genotypes were added as covariables in the chlorophyll evaluation. The linear regression coefficients were significant, with 
positive contribution of the vegetative cycle and the chlorophyll content (Table 1).

negative contribution of the reproductive cycle on

Table 1. Univariate covariance analysis of common bean genotypes in five evaluation periods for physiological senescence $(75,80,85,90$ and 95 days after sowing), plant strata (basal, intermediate and apical) and their interactions. Analysis of the chlorophyll $a$ content, chlorophyll $b$ content (Falker Chlorophyll Index - FCI) and pod color (\%).

\begin{tabular}{|c|c|c|c|c|c|c|}
\hline \multirow{2}{*}{ Source of variation } & \multicolumn{2}{|c|}{ Chlorophyll $a$} & \multicolumn{2}{|c|}{ Chlorophyll $b$} & \multicolumn{2}{|c|}{ Pod color } \\
\hline & DF & MS & DF & MS & DF & MS \\
\hline Block & 2 & 150 & 2 & 126 & 2 & 7518 \\
\hline Genotype (GNT) & 9 & $633^{*}$ & 9 & $399 *$ & 9 & $9109 *$ \\
\hline Season (SES) & 4 & $12497 *$ & 4 & $2986^{*}$ & 2 & $730295^{*}$ \\
\hline $\mathrm{SES} * \mathrm{GNT}$ & 36 & $415^{*}$ & 36 & $224 *$ & 18 & $5212 *$ \\
\hline Strata (STR) & 2 & $3876^{*}$ & 2 & $608 *$ & 2 & $97164 *$ \\
\hline GNT*STR & 18 & $70^{\mathrm{ns}}$ & 18 & $9^{\mathrm{ns}}$ & 18 & $2443 *$ \\
\hline SES*STR & 8 & $638^{*}$ & 8 & $93^{*}$ & 4 & $6259 *$ \\
\hline GNT*SES*STR & 72 & $75^{\mathrm{ns}}$ & 72 & $8^{\mathrm{ns}}$ & 36 & $1336^{\mathrm{ns}}$ \\
\hline Experimental error & 3952 & 94 & 3951 & 20 & 178 & 1640 \\
\hline Covariable & $\beta_{1}$ & & $\beta_{1}$ & & & \\
\hline Vegetative cycle & $0.15^{*}$ & & $0.20 *$ & & & \\
\hline Reproductive cycle & $-0.14^{*}$ & & $-0.48^{*}$ & & & \\
\hline
\end{tabular}

$\beta_{1}$ : Coefficient of linear regression of the covariate effect. $*$ Significant at $5 \%$ probability by the $\mathrm{F}$ test in the analysis of variance and $\mathrm{t}$ test for the regression coefficient. ns non-significant at $5 \%$ probability by the $\mathrm{F}$ test in the analysis of variance and test for the regression coefficient.

Pod discoloration is a common evidence of the physiological maturation. In general, 95 days after sowing, less than $30 \%$ of the pods were green without significant variation (Figure 1). This result shows that the genotypic variability consists in the progression of pod discoloration in the stages between 85 and 90 days after sowing. Therefore, the pods were already dry on the last evaluation date, proving that the variations in chlorophyll contents are due to the late senescence of vegetative structures and not to an extended crop cycle (AGUIAR et al., 2000).

The biological chlorophyll degradation processes can hardly be explained by simpler regression equations, e.g., linear. Interactive analyses were therefore used to fit non-linear regressions. The chlorophyll $a$ degradation for all genotypes and chlorophyll $b$ degradation for six genotypes can be better understood by the function $y=\sqrt{a+b \sqrt{x}}$ (Figure 2). In these cases, chlorophyll degradation has a marked decrease over the first three days of evaluation, followed by a gradual reduction. On the other hand, the chlorophyll $b$ content during senescence of the genotypes BAF045, SPS Preto, FT-Tarumã, and PMP.100 can be represented by second-order regression analysis. 


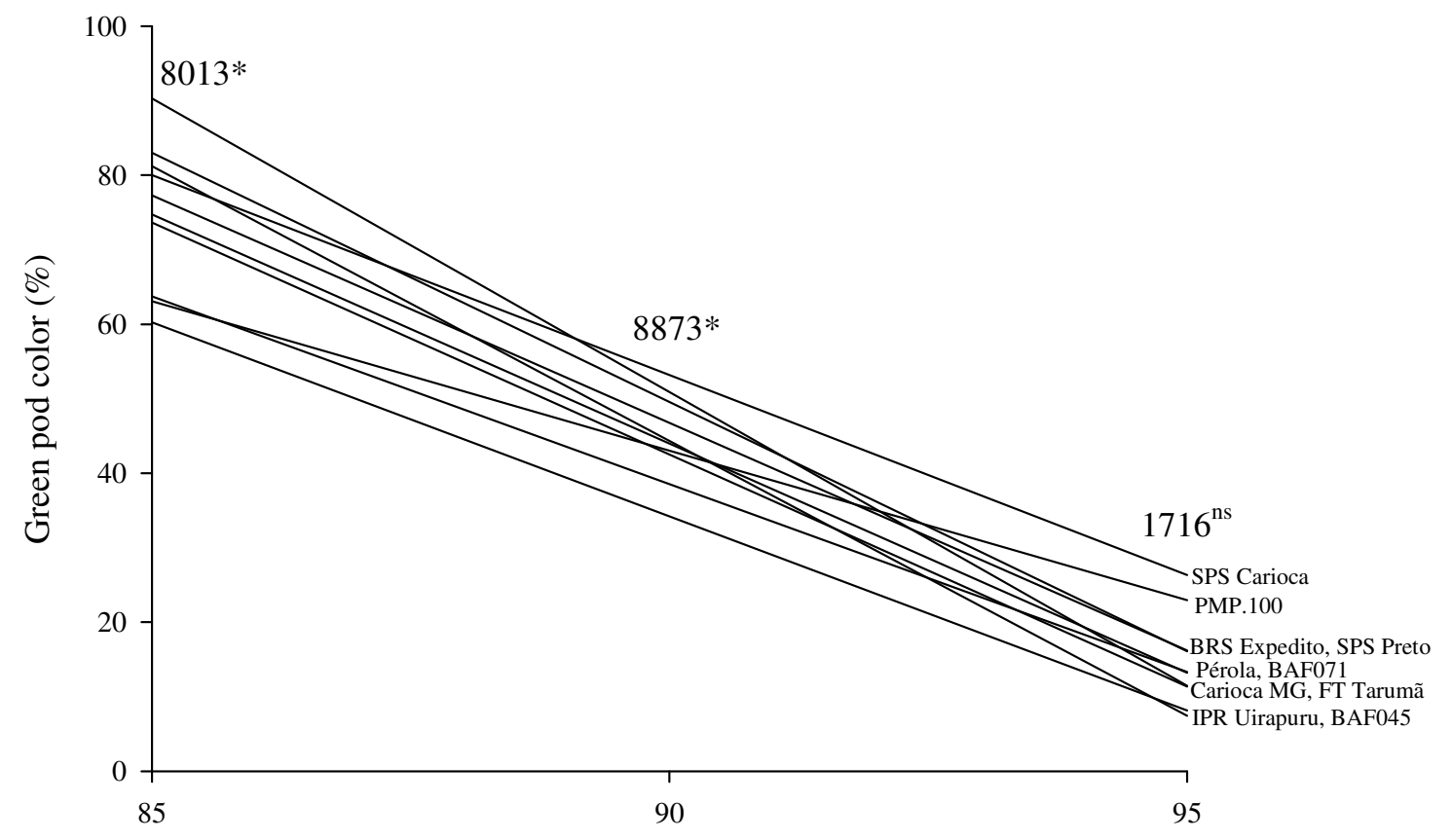

Physiological senescence (days after sowing)

Figure 1. Green pod color (\%) of 10 common bean genotypes during physiological senescence $(85,90$ and 95 days after sowing). Values in the graph represent the mean squares of each evaluation period.

* Significant at $5 \%$ probability by the $\mathrm{F}$ test. ns non-significant at $5 \%$ probability by the $\mathrm{F}$ test.

For genotype BRS Expedito, the degradation of both chlorophyll $a$ and $b$ was accelerated. However, the stay-green trait can be explained by the high chlorophyll $a$ and $b$ contents at the beginning of the evaluation. In the first evaluation 75 days after sowing, the FCI levels of the genotype were 35.80 (chlorophyll $a$ ) and 10.29 (chlorophyll b). Genotype BRS Expedito can naturally intensify metabolic pathways of chlorophyll $a$ and $b$ production during its growth phase, in which molecules are later degraded and used in the senescence metabolism, as in most genotypes (GREGERSEN et al., 2013). Thus, during grain filling the genotype still has photosynthetically active structures. This variant can be classified as stay-green type E (THOMAS; HOWARTH, 2000).

Chlorophyll $a$ and $b$ reduction was less marked in genotype BAF071, compared to the other genotypes. During the evaluation period, a chlorophyll degradation of 13\% FCI (chlorophyll $a$ ) and 27\% FCI (chlorophyll $b$ ) was observed for this genotype (Figure 2). In contrast, in non-stay-green genotypes such as Pérola FCI reductions of $27 \%$ (chlorophyll $a$ ) and 55\% (chlorophyll $b$ ) were observed, as well as for SPS Preto, for which a degradation of 36\% FCI (chlorophyll $a$ ) and 57\% FCI (chlorophyll $b$ ) were measured.

Initially, genotype FT-Tarumã had a higher chlorophyll $a$ content (34.12 FCI) than most other genotypes and a progressively decreasing chlorophyll content, reaching a content of 27.68 FCI until the end of the evaluation. This performance contrasted with the degradation of chlorophyll $b$ content (Figure 2), since chlorophyll $b$ synthesis was detected 75 to 83 days after sowing, with an increase of $21 \%$ FCI.

The gene expression to activate the physiological senescence processes in FT - Tarumã possibly occurs later than in the other evaluated genotypes. At the same time, BAF071 and FTTarumã may have a slow chlorophyll degradation, characterizing functional stay-green types $\mathrm{A}$ and $\mathrm{B}$ (THOMAS; HOWARTH, 2000). However, the degradation of chlorophyll molecules can be interrupted during physiological senescence, while the other age-related events proceed at a rate comparable to non-stay-green genotypes (THOMAS; OUGHAM, 2014). In this case, the plants are classified as type $\mathrm{C}$ or cosmetic staygreen (HÖRTENSTEINER, 2009). Thus, physiological senescence cannot be detected by chlorophyll $a$ and $b$ degradation, i.e., cosmetic stay- 
green is not a trait of agronomic interest (KUSABA

et al., 2013).
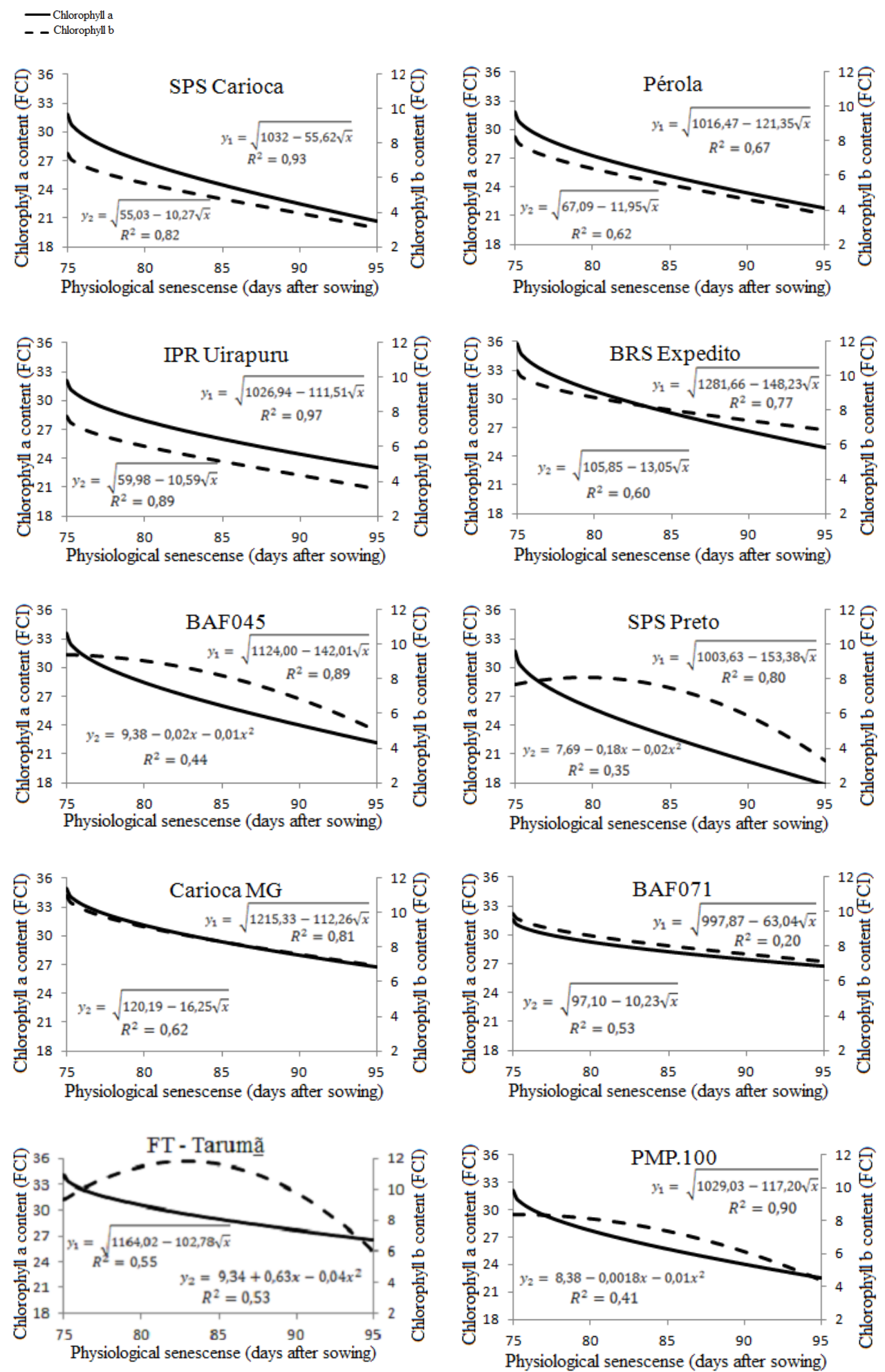

Figure 2. Chlorophyll $a\left(\mathrm{y}_{1}\right)$ and $b\left(\mathrm{y}_{2}\right)$ contents by the Falker chlorophyll index (FCI) in 10 common bean genotypes during physiological senescence $(75,80,85,90$, and 95 days after sowing). Continuous line - chlorophyll $a$, dashed line - chlorophyll $b$.

The effect of the stay-green trait on other traits of agronomic interest (Table 2) consists in a lower incidence and severity of angular leaf spot (mean 52\%), bacterial blight (mean 42\%) and anthracnose (mean 55\%). The possible resistance of the stay-green genotypes to plant diseases may be 
associated with action of the salicylic acid hormone known as promoter of acquired disease resistance, which has metabolic pathways that activate genes related to late senescence (KUSABA et al., 2007).

The stay-green scores are associated with plants with larger stem diameter $(53 \%$ for staygreen score and $50 \%$ for chlorophyll $a$ ). Thus, a better plant architecture with upright growth can be found in late-senescing genotypes. As already detected by Aguiar et al. (2000), the stay-green trait is associated with upright growth in common bean, facilitating the movement of agricultural implements, reducing the contact of pods with the soil and plant lodging. However, a lower lodging index can only be observed in genotypes with a higher chlorophyll $a$ content.

The increase in the vegetative cycle is associated with the stay-green score $(61 \%)$ and chlorophyll contents (83\%) (Table 2). Thus, the selection of genotypes with a longer vegetative cycle without increasing the total common bean cycle may be a viable way to indirectly obtain genotypes with high chlorophyll levels and possibly to delay physiological senescence (stay-green).

The chlorophyll contents were positively associated with the number of pods and grains per plant and negatively with 1000-grain weight (Table 2). Results that may show that higher chlorophyll levels contribute to intensify crop productivity, stimulating the production of more reproductive structures, rather than of grain filling, opposite to what is expected for stay-green genotypes (SILVA et al., 2008). In general, the experiment indicates that grain yields were $39 \%$ associated with staygreen scores and 74\% with chlorophyll $a$ and $63 \%$ with chlorophyll $b$ contents. At the same time, threshing losses from the harvester were detected in a range of $36 \%$ with an increase in the stay-green score. This may be due to the adhesion of the grains in the pod, making threshing during the harvest difficult.

Table 2. Genetic correlation of stay-green scores, chlorophyll $a$ content and chlorophyll $b$ content with traits of agronomic interest for common bean.

\begin{tabular}{|c|c|c|c|c|}
\hline & Agronomic trait & $\begin{array}{l}\text { Stay-green } \\
\text { score }\end{array}$ & $\begin{array}{l}\text { Chlorophyll } \\
\text { content } a\end{array}$ & $\begin{array}{l}\text { Chlorophyll } \\
\text { content } b\end{array}$ \\
\hline \multirow{5}{*}{ 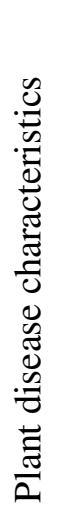 } & Anthracnose on leaves & $0.55^{*}$ & $-0.56^{*}$ & $-0.61^{*}$ \\
\hline & Anthracnose on pods & $0.23^{\mathrm{ns}}$ & $-0.43^{*}$ & $-0.62 *$ \\
\hline & Angular leaf spot on leaves & $0.44 *$ & $-0.52 *$ & $-0.39 *$ \\
\hline & Angular leaf spot on pods & $0.34 *$ & $-0.61^{*}$ & $-0.56^{*}$ \\
\hline & Bacterial infection & $0.42 *$ & $-0.40 *$ & $-0.41 *$ \\
\hline \multirow{6}{*}{ 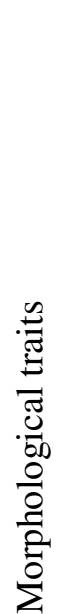 } & Equatorial leaf length (mm) & $-0.24 *$ & $-0.43^{*}$ & $-0.25^{*}$ \\
\hline & Polar leaf length (mm) & $-0.28 *$ & $-0.16^{\mathrm{ns}}$ & $-0.35^{*}$ \\
\hline & Stem diameter $(\mathrm{mm})$ & $-0.53 *$ & $0.50 *$ & $0.38 *$ \\
\hline & First pod height $(\mathrm{cm})$ & $0.05^{\mathrm{ns}}$ & $-0.16^{\text {ns }}$ & $-0.12^{\text {ns }}$ \\
\hline & First pod length $(\mathrm{cm})$ & $0.63^{\mathrm{ns}}$ & $-0.77 *$ & $-0.80^{*}$ \\
\hline & Plant height $(\mathrm{cm})$ & $-0.13^{\text {ns }}$ & $0.04^{\mathrm{ns}}$ & $0.22^{\mathrm{ns}}$ \\
\hline
\end{tabular}




\begin{tabular}{|c|c|c|c|c|}
\hline \multirow{4}{*}{ 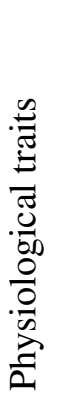 } & Vegetative cycle (days) & $-0.61 *$ & $0.81 *$ & $0.85 *$ \\
\hline & Reproductive cycle (days) & $-0.62 *$ & $0.23 *$ & $0.08^{\mathrm{ns}}$ \\
\hline & Lodging & $0.08^{\mathrm{ns}}$ & $-0.41^{*}$ & $0.22^{\mathrm{ns}}$ \\
\hline & Grain weight lost after threshing $\left(\mathrm{kg} \mathrm{ha}^{-1}\right)$ & $-0.36^{*}$ & $0.06^{\mathrm{ns}}$ & $0.33^{*}$ \\
\hline \multirow{4}{*}{ 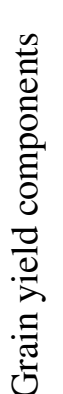 } & Number of pods per plant & $-0.12^{\mathrm{ns}}$ & $0.41 *$ & $0.21 *$ \\
\hline & Number of grains per plant & $-0.18^{\mathrm{ns}}$ & $0.54^{*}$ & $0.38^{*}$ \\
\hline & 1000-grain weight (g) & $0.12^{\mathrm{ns}}$ & $-0.19 *$ & $-0.22 *$ \\
\hline & Grain yield $\left(\mathrm{kg} \mathrm{ha}^{-1}\right)$ & $-0.39 *$ & $0.74 *$ & $0.63 *$ \\
\hline
\end{tabular}

The genotypes BRS Expedito, BAF071 and FT-Tarumã may be excellent parents for the potential fixation of stay-green-related genes. Genotypes with complementary characteristics together with the stay-green genotypes should be used to compose mating blocks. Consequently, segregating populations derived from the controlled hybridizations can be studied in detail. Studies to deepen the understanding of the trait inheritance and selection of promising genotypes should focus on the extended genetic variability. The possibility of fortifying the stay-green trait in pure common bean lines should be further investigated, since it is already being exploited intensively in maize and rice (FISCHER; EDMEADES, 2010).

\section{ACKNOWLEDGEMENTS}

The authors wish to thank the National Council for Scientific and Technological Development $(\mathrm{CNPq})$ and the Coordination for the Improvement of Higher Education Personnel (CAPES) for granting a scholarship and financial support for the development of this study.

RESUMO: Selecionar uma característica relacionada às vias metabólicas responsáveis pelo aumento da resistência e/ou tolerância a estresses bióticos e abióticos pode ser uma excelente alternativa no melhoramento de plantas. Uma abordagem prática para aumentar a produtividade das culturas anuais é maximizar a eficiência fotossintética. $\mathrm{O}$ objetivo do trabalho foi discriminar genótipos de feijão durante a senescência fisiológica quanto ao caráter stay-green e correlacionar os efeitos sobre outros caracteres de interesse agronômico. Foram avaliados dez genótipos de feijão submetidos ao delineamento de blocos casualizados com três repetições. O caráter stay-green foi mensurado por escores de notas visuais na colheita. Também foram avaliados o teor de clorofila $a$, teor de clorofila $b$ e coloração verde do legume no decorrer da senescência $(75,80,85,90,95$ dias após semeadura). A maturação dos legumes foi padrão para todos os genótipos avaliados. Os genótipos BRS Expedito, FT - Tarumã e BAF071 apresentaram stay-green, diferentemente dos demais. A variabilidade genética nos mecanismos relacionados a senescência tardia, são detectadas pela: $i$ ) elevado teor de clorofila $a$ inicial; e $i i)$ reduzida degradação de clorofila ao longo da senescência. As plantas com stay-green apresentaram correlações significativas com menor incidência e severidade de fitopatologias, maior diâmetro do caule e rendimento de grãos.

PALAVRAS-CHAVE: Phaseolus vulgaris L. Análise de covariância. Senescência tardia. Estresse abiótico e biótico. 


\section{REFERENCES}

AGUIAR, A. M.; RAMALHO, M. A. P.; MARQUES JÚNIOR, O.G. Controle genético do stay-green no feijoeiro (Phaseolus vulgaris L.). Revista Ceres, v. 47, p. 155-167, 2000.

ASSEFA, T.; WU, J.; BEEBE, S.E.; RAO, I.M.; MARCOMIN, D.; CLAUDE, R.J. Improving adaptation to drought stress in small red common bean: phenotypic differences and predicted genotypic effects on grain yield, yield components and harvest index. Euphytica, v. 203, n. 3 p. 477-489, 2015.

http://dx.doi.org/10.1007/s10681-014-1242-x.

BACHMANN, A.; FERNÁNDEZ-LÓPEZ, J.; GINSBURG, S.; THOMAS, H.; BOUWKAMP, J.C.;

SOLOMOS, T.; MATILE, P. Stay-green genotypes of Phaseolus vulgaris: Chloroplast proteins and chlorophyll catabolites during foliar senescence. The New Phytologist, v. 126, n. 4, p. 593-600, 1994.

http://dx.doi.org/10.1111/j.1469-8137.1994.tb02953.x.

BORRELL, A.K.; HAMMER, G.L. Nitrogen Dynamics and the Physiological Basis of Stay-Green in Sorghum. Crop Science, v. 40, n. 5. p. 1295-1307, 2000. http://dx.doi.org/10.2135/cropsci2000.4051295x.

CARMO, S. L. M.; SANTOS, J. B.; HAGIWARA, W. E.; FERREIRA, J. L. Avaliação do 'stay green' em famílias segregantes de feijão (Phaseolus vulgaris L.). Ciência e Agrotecnologia, v. 31, n. 4. p. 953-957, 2007. http://dx.doi.org/110.1590/S1413-70542007000400002.

DOHLEMAN F.G.; LONG S. P. (2009). More productive than maize in the midwest: how does Miscanthus do it? Plant Physiology, v. 150, n. 4, p. 2104-2115. http://dx.doi.org/10.1104/pp.109.139162.

FAHAD, S.; BAJWA, A. A.; NAZIR, U.; ANJUM, S. A.; FAROOQ, A.; ZOHAIB, A.; SADIA, S.; NASIM, W.; ADKINS, S.; SAUD, S.; IHSAN, M. Z.; ALHARBY, H.; WU, C.; WANG, D.; HUANG, J. Crop production under drought and heat stress: plant responses and management options. Frontiers in Plant Science, v. 8, p. 1-16, 2017. http://dx.doi.org/10.3389/fpls.2017.01147.

FISCHER, R. A.; EDMEADES, G.O. Breeding and cereal yield progress. Crop Science, v. 50, p.85-98, 2010. http://dx.doi.org/10.2135/cropsci2009.10.0564.

GREGERSEN, P. L.; CULETIC, A.; BOSCHIAN, L.; KRUPINSKA, K. Plant senescence and crop productivity. Plant Molecular Biology, v. 82, n. 6, p. 603-622, 2013 http://dx.doi.org/10.1007/s11103-0130013-8.

HÖRTENSTEINER, S. Stay-green regulates chlorophyll and chlorophyll-binding protein degradation during senescence. Trends Plant Science, v. 14, p. 155-162, 2009. http://dx.doi.org/10.1016/j.tplants.2009.01.002.

KUSABA, M.; ITO, H.; MORITA, R.; IIDA, S.; SATO, Y.; FUJIMOTO, M.; KAWASAKI, S.; TANAKA, R.; HIROCHIKA, H.; NISHIMURA, M.; TANAKA, A. Rice non-yellow coloring1 is involved in light-harvesting complex II and grana degradation during leaf senescence. Plant Cell, v. 19, n. 4, p. 1362-1375, 2007.

http://dx.doi.org/10.1105/tpc.106.042911.

KUSABA, M.; TANAKA, A.; TANAKA, R. Stay-green plants: what do they tell us about the molecular mechanism of leaf senescence. Photosynth Res, v. 117, n. 1-3, p. 221-234, 2013.

http://dx.doi.org/10.1007/s11120-013-9862-x.

LIM P.O.; KIM, H. J.; NAM, H. G. Leaf senescence. Annual Review of Plant Biology, v. 58, p. 115-136, 2007. https://doi.org/10.1146/annurev.arplant.57.032905.105316.

MESQUITA, C. M.; COSTA, N. P.; MANTOVANI, E. C.; ANDRADE, J. G. M.; FRANCA NETO, J. B.; SILVA, J. G.; FONSECA, J. R.; PORTUGAL, F. A. F.;GUIMARAES SOBRINHO, J. B. (1998). Manual do produtor: como evitar desperdícios nas colheitas de soja, do milho e do arroz. Londrina: EMBRAPA. 
MONJE O. A.; BUGBEE, B. Inherent limitations of nondestructive chlorophyll meters: a comparison of two types of meters. Horticultural Science, v. 27, p. 69-71, 1992. https://doi.org/10.21273/HORTSCI.27.1.69

MURAKAMI, P. F.; TURNER, M.R.; VAN DEN BERG, A. K.; SHABERG, P.G. (2005). An instructional guide for leaf color analysis using digital imaging software. Pennsylvania: Department of Agriculture, Forest Service, Northeastern Research Station. https://doi.org/10.2737/NE-GTR-327

SCHOONHOVEN, A. V. AND PASTOR CORRALES, M.A. (1987). Sistema Estándar para la evaluación de germoplasma de frijol. Cali: CIAT.

SILVA, J. A. G.; CARVALHO, F. I. F.; HARTWIG, I.; OLIVEIRA, A.C.; BERTAN, I.; CAETANO, V. R.; SCHMIDT, D. A. M.; VALÉRIO, I. P.; RIBEIRO, G.; BUSATO, C.C. Caráter stay-green e produtividade de grãos em trigo. Bragantia, v. 67, n. 1, p. 161-167, 2008. http://dx.doi.org/10.1590/S0006-87052008000100020.

THOMAS, H.; HOWARTH, C.J. Five ways to stay green. Journal of Experimental Botany, v. 51, n. suppl_1, p. 329-337, 2000. https://doi.org/10.1093/jexbot/51.suppl_1.329.

THOMAS, H.; OUGHAM, H. The stay-green trait. Journal of Experimental Botany, v. 65, n. 14, p. 38893900. https://doi.org/10.1093/jxb/eru037.

WALULU, R.S.; ROSENOW, D.T.; WESTER, D.B.; NGUYEN, H.T. Inheritance of the stay green trait in sorghum. Crop Science, v. 34, n. 4, p. 970-972, 1994.

https://doi.org/10.2135/cropsci1994.0011183X003400040026x.

WANG, F., WANG, G., LI, X., HUANG, J. AND ZHENG, J. Heredity, physiology and mapping of a chlorophyll content gene of rice (Oryza sativa L.). Journal of plant physiology, v. 165, n. 3, p. 324-330, 2008. https://doi.org/10.1016/j.jplph.2006.11.006.

ZHU, X.G.; LONG, S.P.; ORT, D.R. Improving photosynthetic efficiency for greater yield. Annual Review of Plant Biology, v. 61, p. 235-261, 2010. https://doi.org/10.1146/annurev-arplant-042809-112206. 